\title{
Efficiency of Bacillus thuringiensis strains and their Cry proteins against the Red Flour Beetle, Tribolium castaneum (Herbst.) (Coleoptera: Tenebrionidae)
}

\author{
Karam Khamis Elgizawy ${ }^{1,2^{*}}$ and Noha Mohamed Ashry ${ }^{3}$
}

\begin{abstract}
Bacillus thuringiensis $(B t)$ is one of the used bioagents in insect pest control. Its toxicity is largely due to the insecticide endotoxins (crystalline (Cry) proteins) that act selectively on insects and nematodes. The efficiency of 20 of the most common Coleopteran-specific Cry proteins of Bt strains was tested against third instar-larvae of the red flour beetle Tribolium castaeum (Herbst.) (Coleoptera: Tenebrionidae). The primary screening results revealed that 11 Cry proteins (Cry8Ea, Cry8Fa, Cry1Ba, Cry8Ca, Cry1Fb, Cry1Ea, Cry1Ca, Cry55Aa, Cry9Da, Cry1Da, and Cry1la) were not toxic at all, 4 Cry proteins (Cry1Aa, Cry14Aa, Cry8Aa, and Cry7Ab) did not cause mortality but caused significant inhibition of growth, and 5 Cry proteins (Cry3Aa, Cry37Aa, Cry22Aa, Cry51Aa, and Cry3Ba) were toxic to T. castaneum larvae. The active 5 Cry proteins were used in the subsequent experiments. Five concentrations, being $0.25,0.5,1.0,1.5$, and $2.0 \mathrm{~g}$ Cry protein $/ 10 \mathrm{~g}$ diet were used against the third instar larvae, and their mortalities were estimated. The $L_{50}$ values of Cry3Aa, Cry37Aa, Cry22Aa, Cry51Aa, and Cry3Ba were 0.46, 0.77, 1.25, 1.45, and 1.60 g/ $10 \mathrm{~g}$, respectively. While the $L T_{50}$ values of the same Cry proteins (for the concentration $2 \mathrm{~g} / 10 \mathrm{~g}$ diet) were 1.50, $1.93,2.29,2.23$, and 4.22 days, respectively. The results indicated that Cry3Aa was the most active one against $T$. castaneum larvae. The results of the sublethal study showed that the application of $L_{30}$ value of the active 5 Cry proteins reduced total eggs laid daily per female within 2 weeks, where, the percent decrease in egg numbers were 50.55, 38.56, 31.31, 23.20, and, 18.10\% for Cry3Aa, Cry37Aa, Cry22Aa, Cry51Aa, and Cry3Ba, respectively. In addition, the hatchability rate of eggs, the larval, and pupal durations of $T$. castaneum decreased, while the preovipositional period was prolonged. Furthermore, the larvae fed on a diet containing $L C_{30}$ concentrations of Cry protein showed lower glycogen and lipid rates and generally lower protein content than the control larvae. When T. castaneum larvae were treated by Cry proteins, the level of digestive enzymes found in the midgut was decreased. The present findings indicated that Bt strains/Cry proteins had significant potential for controlling $T$. castaneum
\end{abstract}

Keywords: Tribolium castaneum, Bacillus thuringiensis, Bioassay, Sublethal concentrations, Digestive enzymes

\footnotetext{
*Correspondence: Karam.elgizawy@fagr.bu.edu.eg

${ }^{1}$ College of Life Science and Technology, Huazhong Agricultural University,

Wuhan 430070, China

${ }^{2}$ Plant Protection Department, Faculty of Agriculture, Benha University, Toukh

13736, Egypt

Full list of author information is available at the end of the article
} 


\section{Background}

Grains production is an important dietary component of human food in many countries. It is a good source of carbohydrates, vitamins, and some minerals, including trace elements like selenium in vegetarian diets of the majority of the population of the world (Poutanen, 2012). Stored grains insect pests can harm the national economy by infesting agricultural stored products (Jembere et al. 1995). The red flour beetle, Tribolium castaneum (Herbst.) (Coleoptera: Tenebrionidae) is a worldwide common pest of wheat flour. It also feeds upon dry fruits, pulses, and prepared cereal foods, where both larvae and adult beetles cause damage (Weston and Rattlingourd, 2000). The traditional control treatments in many countries depend on fumigants. Safety and environmental issues surrounding the use of chemical insecticides have led to a focus on the development of alternative control measures. One of the main effective alternatives to chemical control of insect pests is the biological control in nematodes as well as microbial agents viz., bacteria, fungi, viruses and protozoa (Cannon, 1993).

Among all the microbial agents, Bacillus thuringiensis $(B t)$ is considered one of the most common and widely used biological pesticide against insect pests (Lemaux, 2008). Various types of $B t$ formulations are available in the market as a liquid and powders and represent $90 \%$ of all types of bioagents sold today. Bt produces different kinds of poisons with insecticidal efficiency. Proteinaceous protoxins forming crystals parallel to the $B t$ spores during sporulation and known as Cry proteins play an important role in $B t$ toxicity. Various Bt strains produce in excess of 200 diverse Cry protoxins that act selectively on narrow ranges of hosts (Bravo et al. 2007). In light of their insecticidal toxicity and amino acid sequences, they have been divided into groups numbered from Cry1 to Cry55 (Crickmore et al. 2014). Each group involves various subgroups classes and subclasses that differ in specificity and activity. The significance of Cry toxins has extraordinarily expanded over the most recent 20 years when the genes encoding them were introduced into plants (Gould, 1998). Genetically modified crops expressing Cry proteins are resistant to specific pests without influencing different segments of the agro-ecosystems (Yu et al. 2011). Cry proteins are converted to active poisons by incomplete proteolytic cleavage that happens in the insect midgut (Ferre and Van Rie, 2002). Active toxin at that point ties to a particular receptor and is along these lines irreversibly embedded into the brush outskirt membrane of the epithelial midgut cells (Gilliland et al. 2002 and Hernandez et al. 2004). The membrane becomes punctured, and subsequent uncontrolled take-up of ions and water prompts the expanding of midgut cells and their possible lysis (Bravo et al. 2007). The insect dies because of general septicemia. It must be noticed that insect species significantly change in their susceptibility to $B t$ and that the susceptible species can develop resistance whenever exposed to a Cry toxin for various generations (Tabashnik et al. 2003).

In the present study, the potential of 20 common Coleopteran-specific Cry proteins was determined and the most active 5 ones were evaluated against third instar larvae of $T$. castaneum based on $\mathrm{LC}_{50}$ values. Some biological parameters and digestive enzyme activity were assessed in larvae that fed on an artificial diet containing sublethal concentrations of Cry protein.

\section{Materials and methods \\ Rearing of experimented species}

Rearing of $T$. castaneum was carried out by collecting adults from infested wheat flour, dry fruits, grains, rice, semolina, etc. These adults were placed in glass jars of $300 \mathrm{ml}$ capacity. Each jar was filled with $1 / 4$ sterilized mixture of the diet regimen comprising of $90 \%$ semolina and $10 \%$ yeast extract. Fifty adults were added to each jar. Every third day, a new diet was added to acquire enough larvae and adults for bioassay experimentation. The larvae were reared at $30 \pm 1{ }^{\circ} \mathrm{C}$ and $60 \pm 5 \% \mathrm{RH}$. The third instar larvae and newly emerged adults were obtained and used in bioassay experiments.

\section{Bacillus thuringiensis strain}

$B t$ has different Cry toxin protein types, each type usually acts on separate orders of insects (Crickmore et al. 1998). Twenty of the most common Coleopteran-specific Bt strains, which produce specific Cry proteins, were obtained from the State Key Laboratory of Agricultural Microbiology, Huazhong Agricultural University (Wuhan City, Hubei Province, China). Efficacy of 20 strains, listed in Table 1 was evaluated against, T. castaneum.

\section{Microbiological technique}

$B t$ strains were grown on Petri plates containing LuriaBertani (LB) medium supplemented with the appropriate antibiotics at $28{ }^{\circ} \mathrm{C}$ for $24 \mathrm{~h}$. For Cry protein production, the $B t$ strains were cultivated in a liquid ICPM medium (0.6\% tryptone, $0.5 \%$ glucose, $0.1 \% \mathrm{CaCO}_{3}, 0.05 \% \mathrm{MgSO}_{4}$, and $0.05 \% \mathrm{~K}_{2} \mathrm{HPO}_{4}, \mathrm{PH} 7.0$ ) at $28{ }^{\circ} \mathrm{C}, 220 \mathrm{rpm}$ for 3 days until cell lysis and complete sporulation. Smears of bacteria were stained by a simple stain for $1 \mathrm{~min}$, washed with tap water, dried and observed under a light microscope to check the crystal production and morphology. After that, the culture was separated through centrifugation at 10000 rpm for 2-3 min. The collected sediment of $B t$ was mixed with distilled water and centrifuged at $300 \mathrm{rpm}$ for $5 \mathrm{~min}$. This centrifugation was repeated thrice in centrifugation tubes till all the media was washed away and the supernatant was discarded. At the bottom of the tube, the sediment was obtained, which was dried in an oven. The dried sediment was crushed in a pestle mortar to form the fine granule like powder. 
Table 1 Different Bacillus thuringiensis strains and their cry proteins

\begin{tabular}{|c|c|c|c|c|c|}
\hline No. & Bt strain & The produced Cry protein & No. & Bt strain & The produced Cry protein \\
\hline 1 & 20140314RJT017 & Cry1Aa & 11 & 20140926WHНT029 & Cry8Aa \\
\hline 2 & 20140308 CSFT034 & Cry1Ba & 12 & $20150611 X A R T 270$ & Cry8Ca \\
\hline 3 & 20140923LMMT088 & Cry1Ca & 13 & $20150611 X A R T 270$ & Cry8Ea \\
\hline 4 & 20140923LMMT088 & Cry1Da & 14 & 20141227ZHT080 & Cry8Fa \\
\hline 5 & 20140221 WWHT003 & Cry1Ea & 15 & 20141023WST136 & Cry9Da \\
\hline 6 & 20141023WST132 & Cry1Fb & 16 & 20141202CGP002 & Cry14Aa \\
\hline 7 & $20140907 C D W T 115$ & Cry1la & 17 & $20141126 C$ CLT002 & Cry22Aa \\
\hline 8 & 20140919KYYT015 & Cry3Aa & 18 & 20141008WHНT043 & Cry37Aa \\
\hline 9 & 20140728LTT243 & Cry3Ba & 19 & 20131204YWYT028 & Cry51Aa \\
\hline 10 & 20131203LTT036 & Cry7Ab & 20 & 20140415YJPT508 & Cry55Aa \\
\hline
\end{tabular}

\section{Insect bioassays}

Insect bioassays included incorporating the toxin protein into the artificial insect diet was carried out in two steps (MacIntosh et al. 1990). In the first step, the susceptibility of T. castaneum larvae to each Cry toxin tested was determined at a high protein concentration ( $2 \mathrm{~g}$ toxin/10 $\mathrm{g}$ diet) by incorporating the poison into the diet that offered to 30 larvae. The second step involved the determination of the $\mathrm{LC}_{50}$ for active Cry proteins. The concentration range used for each Cry protein was determined in preliminary bioassays. Thirty larvae were treated by each protein concentration. A variety of 5 concentrations $(0.25,0.5,1.0,1.5$, and $2.0 \mathrm{~g})$ were used for each toxin and mixed with a ten-gram diet, that is, 8 g semolina and $2 \mathrm{~g}$ of yeast extract. These concentrations were poured in glass vials and introduced 30 larvae in each vial separately. The bioassay was carried out three times. Control insects were fed an artificial diet without toxin. The insects' treatment were incubated at $25{ }^{\circ} \mathrm{C}$ and $60 \% \mathrm{RH}$. Mortality was observed, 1 day for 7 days. Data was analyzed by the probit analysis program and the $\mathrm{LC}_{50}$ was calculated.

\section{Sublethal effects}

The effect of sublethal concentrations ( $\left.\mathrm{LC}_{30}\right)$ of five active Cry proteins on certain biological aspects of T. castaneum adults was evaluated. The adults of $T$. castaneum (2 days old) were fed on the treated diet ( $\mathrm{LC}_{30}$ of Cry protein) in a glass vial for 7 days. Then, certain biological aspects of surviving adults after treatment were studied to assess the number of eggs laid by a female for 14 days. Unmated females were paired in $3 \times 4 \mathrm{~cm}$ glass tubes, containing small amounts of wheat flour, and covered with muslin. For estimating the incubation period of eggs and the developmental periods for the various stages, 1-day-old eggs were used. Individually, 10 replicates were used for each treatment. The incubation period of the egg was recorded. The developmental stages were observed, and their durations were also estimated. In this respect, the following parameters were recorded: average number of eggs laid daily per female, average total number of eggs laid per $\mathrm{f}$ emale during 2 weeks, pre-ovipositional period, incubation period of eggs, hatchability of eggs, average duration of larval stage, duration of pupal stage, and total developmental period of immature stages.

\section{Biochemical analyses}

For the biochemical studies, the third instar larvae were permitted to feed on a diet containing Cry proteins as well as the control diet. After 5 days of feeding on diets, larvae from each treatment were cold anesthetized independently at $5{ }^{\circ} \mathrm{C}$. Consequently, total protein, glycogen, and lipid content were determined, and control larvae were treated for estimating the following components as depicted underneath. For each treatment, 6 to 8 replicates were used. To determine protein concentration, the strategy of Lowry et al. 1951 was used, while to estimate the glycogen content anthrone reagent was used and described by Yuval et al. 1998 with some modifications. Whilst to determine lipid content, lipids were extracted from individual larvae according to Van Handel, (1985) with some modifications.

\section{Digestive enzyme activity assays}

Third-instar larvae of T. castaneum were fed on a diet containing a concentration of $\mathrm{LC}_{30}$ value Cry proteins and reared as explained before. After 5 days post-treatment, the surviving larvae were individually Nathan submerged in ice-cold $0.15 \mathrm{M} \mathrm{NaCl}$, and the midguts were dissected by the aid of a stereomicroscope (Stemi SV6 ZEISS, Germany) according to Borzoui and Bandani, 2013. The $\alpha$-amylase activity was determined using the method of Bernfeld, 1955, using $1 \%$ starch as a substrate in the Tris- $\mathrm{HCl}$ buffer $(\mathrm{pH}$ 8). General proteolysis activity was determined by the method of Elpidina et al. 2001, using 1.5\% azocasein as a substrate in a glycine- $\mathrm{NaOH}$ buffer ( $\mathrm{pH} 10)$. 


\section{Data analyses}

The data were corrected according to Abbott's formula (Abbott, 1925), and they were subjected to probit analysis using LDP line software according to Finney, 1971 to estimate $\mathrm{LC}_{30}, \mathrm{LC}_{50}$, and $\mathrm{LC}_{99}$ values of Cry proteins against third instar larvae of $T$. castaneum. Mortality percentages for different exposure times were subjected to analysis of variance (one-way ANOVA), using the statistical program (SPSS 2001) for probit analysis (Steel et al. 1997).

\section{Results and discussion}

\section{Toxicity of Bt strains/Cry toxins}

T. castaneum larvae showed different degrees of susceptibility to 20 of the most common Coleopteran-specific Cry proteins produced by $B t$ strains. At the concentration tested ( $2 \mathrm{~g}$ of toxin/10 $\mathrm{g}$ of artificial diet), the mortality percentages obtained with $11 \mathrm{Bt}$ strains/Cry toxins (Cry8Ea, Cry8Fa, Cry1Ba, Cry8Ca, Cry1Fb, Cry1Ea, Cry1Ca, Cry55Aa, Cry9Da, Cry1Da, and Crylla) were non-significantly different than those from the control larvae (reared on a toxin-free diet). Consequently, when a Cry toxin caused no mortality in $T$. castaneum, it was attributed to the lack of toxic activity of that particular Cry toxin or a reduced feeding rate on the toxin-contaminated diet. No mortality was observed with 4 Bt strains/Cry protein (Cry1Aa, Cry14Aa, Cry8Aa, and $\mathrm{Cry} 7 \mathrm{Ab}$ ), but those caused significant inhibition of growth. Five Bt strains/Cry proteins (Cry3Aa, Cry37Aa, Cry22Aa, Cry51Aa, and Cry3Ba) were toxic against $T$. castaneum larvae and resulted in larval mortality, which increased as the concentration was increased. These active $5 \mathrm{Cry}$ toxins were used in the subsequent experiments.

\section{Mortality of $T$. castaneum after feeding on diet contaminated with Cry toxin}

Third instar larvae of $T$. castaneum were susceptible to the 5 Cry protein treatments showing high toxicity when incorporated into the diet. The $\mathrm{LC}_{30}, \mathrm{LC}_{50}$, and $\mathrm{LC}_{99}$ of
Cry proteins are presented in Table 2 . The lowest $\mathrm{LC}_{50}$ value (highest toxicity) against third instar larvae of $T$. castaneum was with Cry3Aa $(0.46 \mathrm{~g} / 10 \mathrm{~g})$, followed by Cry37Aa, Cry22Aa, Cry51Aa, and Cry3Ba (0.77, 1.25, 1.45 , and $1.60 \mathrm{~g} / 10 \mathrm{~g}$ ), respectively. The $\mathrm{LT}_{30}, \mathrm{LT}_{50}$, and $\mathrm{LT}_{99}$ values of Cry proteins to third instar larvae of $T$. castaneum are shown in Table 3 . The results showed that the efficacy of Cry3Aa was faster than the other Cry proteins, followed by Cry37Aa, Cry22Aa, Cry51Aa, and Cry3Ba, respectively. The cumulative mortality percentage on third instar larvae of $T$. castaneum after 7 days of exposure and different concentrations of Cry proteins were shown in Fig. 1. The mortality percentage increased with increasing concentrations of Cry proteins. Generally, the active $5 \mathrm{Bt}$ strains, which produced Cry proteins had toxic effects on third instar larvae of $T$. castaneum, although the toxicity of Cry3Aa was the highest.

Isolation and characterization of $B t$ strains is a common practice in search of biocontrol of insect pests (Magda, 2006). Nonetheless, investigators continued to seek new strains of $B t$ from diverse habitats, as each strain produces its characteristic effectiveness of its crystal protein, and the insecticidal activity of these proteins also differs considerably. In the present study, the screened strains were analyzed using a toxicity bioassay for their potency against $T$. castaneum larvae; which is known as one of the most damaging insects to stored grain products worldwide (Toews et al. 2005). Also, $B t$ is already reported as an effective biocontrol agent against lepidopteran and coleopteran larvae (Tamez-Guerra et al. 2004). The isolated toxins from various Cry proteins were tested by five concentrations $(0.25$, $0.50,1.00,1.5$, and $2 \mathrm{~g} / 10 \mathrm{~g}$ ). The results were found to be dosage-dependent, and the percentage mortality of the tested insect increased in proportion with increased toxin concentration. In the present study, the results are in harmony with Van Frankenhuyzen, 2009 who found that Cry3Aa and Cry37Aa had activity against T. castaneum, also López-Pazos et al. 2009 found that Cry1B and Cry3

Table 2 Lethal and sublethal concentrations of various Cry proteins against third instar larvae of Tribolium castaneum 7 days post treatment

\begin{tabular}{|c|c|c|c|c|c|c|c|}
\hline \multirow{2}{*}{$\begin{array}{l}\text { Bt strains/Cry } \\
\text { proteins }\end{array}$} & \multicolumn{3}{|c|}{ Lethal concentration $\pm 95 \%$ F.L $L^{a}$. (g/10g diet ) } & \multirow[t]{2}{*}{ Slope \pm SD } & \multirow[t]{2}{*}{ Chi square $\left(x^{2}\right)$} & \multirow[t]{2}{*}{$p$ value } & \multirow[t]{2}{*}{$R$. } \\
\hline & LC30 & LC50 & LC99 & & & & \\
\hline $\begin{array}{l}\text { 20140919KYYT015 } \\
\text { Cry3Aa }\end{array}$ & $\begin{array}{l}0.13 \\
0.05-0.20\end{array}$ & $\begin{array}{l}0.46 \\
0.32-0.58\end{array}$ & $\begin{array}{l}35.97 \\
14.46-193.13\end{array}$ & $1.22 \pm 0.18$ & 4.12 & 0.24 & 0.952 \\
\hline $\begin{array}{l}\text { 20150420LHMT145 } \\
\text { Cry37Aa }\end{array}$ & $\begin{array}{l}0.21 \\
0.10-0.30\end{array}$ & $\begin{array}{l}0.77 \\
0.60-0.97\end{array}$ & $\begin{array}{l}67.66 \\
23.48-493.82\end{array}$ & $1.19 \pm 0.18$ & 4.78 & 0.18 & 0.945 \\
\hline $\begin{array}{l}\text { 20141126CLLT002 } \\
\text { Cry22Aa }\end{array}$ & $\begin{array}{l}0.31 \\
0.17-0.44\end{array}$ & $\begin{array}{l}1.25 \\
0.97-1.75\end{array}$ & $\begin{array}{l}143.10 \\
39.31-1857.32\end{array}$ & $1.13 \pm 0.19$ & 2.89 & 0.40 & 0.962 \\
\hline $\begin{array}{l}\text { 20131204YWYT02 } \\
\text { 8Cry51Aa }\end{array}$ & $\begin{array}{l}0.31 \\
0.15-0.44\end{array}$ & $\begin{array}{l}1.45 \\
1.09-2.28\end{array}$ & $\begin{array}{l}296.91 \\
60.05-9538.04\end{array}$ & $1.00 \pm 0.19$ & 3.66 & 0.29 & 0.942 \\
\hline $\begin{array}{l}\text { 20140728LTT243 } \\
\text { Cry3Ba }\end{array}$ & $\begin{array}{l}0.38 \\
0.21-0.52\end{array}$ & $\begin{array}{l}1.60 \\
1.21-2.51\end{array}$ & $\begin{array}{l}229.43 \\
52.95-4823.27\end{array}$ & $1.07 \pm 0.19$ & 0.91 & 0.82 & 0.985 \\
\hline
\end{tabular}

${ }^{\mathrm{a}} 95 \%$ Fiducial limits 
Table 3 Lethal and sublethal times of various Cry proteins after treatment of third instar larvae of Tribolium castaneum at the highest concentration $(2 \mathrm{~g} / 10 \mathrm{~g})$

\begin{tabular}{|c|c|c|c|c|c|c|c|}
\hline \multirow{2}{*}{$\begin{array}{l}\text { Bt strains/Cry } \\
\text { proteins }\end{array}$} & \multicolumn{3}{|c|}{ Lethal time (day) $\pm 95 \%$ F.L L $^{a}$} & \multirow[t]{2}{*}{ Slope \pm SD } & \multirow[t]{2}{*}{ Chi Square $\left(x^{2}\right)$} & \multirow[t]{2}{*}{$p$ value } & \multirow[t]{2}{*}{$R$} \\
\hline & LT30 & LT50 & LT99 & & & & \\
\hline $\begin{array}{l}\text { 20140919KYYT015 } \\
\text { Cry3Aa }\end{array}$ & $\begin{array}{l}0.68 \\
0.44-0.90\end{array}$ & $\begin{array}{l}1.50 \\
1.19-1.78\end{array}$ & $\begin{array}{l}22.71 \\
14.77-44.42\end{array}$ & $1.97 \pm 0.22$ & 5.68 & 0.12 & 0.971 \\
\hline $\begin{array}{l}\text { 20150420LHMT145 } \\
\text { Cry37Aa }\end{array}$ & $\begin{array}{l}0.77 \\
0.49-1.04\end{array}$ & $\begin{array}{l}1.93 \\
1.55-2.29\end{array}$ & $\begin{array}{l}44.76 \\
25.15-115.31\end{array}$ & 1.700 .21 & 4.14 & 0.24 & 0.971 \\
\hline $\begin{array}{l}20141126 C \text { CLT002 } \\
\text { Cry22Aa }\end{array}$ & $\begin{array}{l}0.79 \\
0.45-1.10\end{array}$ & $\begin{array}{l}2.29 \\
1.82-2.77\end{array}$ & $\begin{array}{l}89.54 \\
41.13-354.89\end{array}$ & 1.460 .21 & 2.28 & 0.51 & 0.978 \\
\hline $\begin{array}{l}\text { 20131204YWYT02 } \\
\text { 8Cry51Aa }\end{array}$ & $\begin{array}{l}1.22 \\
0.83-1.56\end{array}$ & $\begin{array}{l}3.23 \\
2.71-3.89\end{array}$ & $\begin{array}{l}92.15 \\
44.37-319.17\end{array}$ & 1.590 .21 & 0.38 & 0.94 & 0.996 \\
\hline $\begin{array}{l}\text { 20140728LTT243 } \\
\text { Cry3Ba }\end{array}$ & $\begin{array}{l}1.66 \\
1.24-2.04\end{array}$ & $\begin{array}{l}4.22 \\
3.55-5.23\end{array}$ & $\begin{array}{l}104.01 \\
49.77-360.90\end{array}$ & 1.670 .22 & 0.18 & 0.98 & 0.998 \\
\hline
\end{tabular}

${ }^{a} 95 \%$ Fiducial limits

proteins from $B t$ were toxic to coleopteran beetles such as the Colorado potato beetle and the cottonwood leaf beetle. The toxin crystals are known to dissolve easily in the insect midgut, liberating the protoxin, which then undergoes proteolysis where one of the fragments binds to the cells of the midgut epithelium. The activated protein is reported to disrupt the osmotic balance of insect cells by forming pores in the cell membrane. The insects stop feeding due to gut paralysis and die within a few hours of ingestion (Marrone and Macintosh, 1993). A variation was observed in the toxicity of various Cry proteins against T. castaneum. The highest mortality percentage resulted from Cry3Aa, followed by the isolates from Cry37Aa, Cry22Aa, and Cry51Aa, whereas the least activity effect was found when Cry3Ba was used against the target insect. Calculation of $\mathrm{LC}_{50}$ re-established these results, and the lowest $\mathrm{LC}_{50}$ was recorded for Cry3Aa, confirming it as the best potential source of the toxin, whereas the highest $\mathrm{LC}_{50}$ concentration (lowest potentiality) was recorded from Cry3Ba. These results confirmed the possible use of $B t$ strain toxin as a bio-insecticide against $T$. castaneum. These findings can guide future choices for environmentally friendly, integrated pest management strategies.

Effect of sublethal concentrations on $T$. castaneum adults The effect of sublethal concentrations $\left(\mathrm{LC}_{30}\right)$ of 5 Cry protein on certain biological aspects of $T$. castaneum adults was evaluated and listed in Table 4. The results

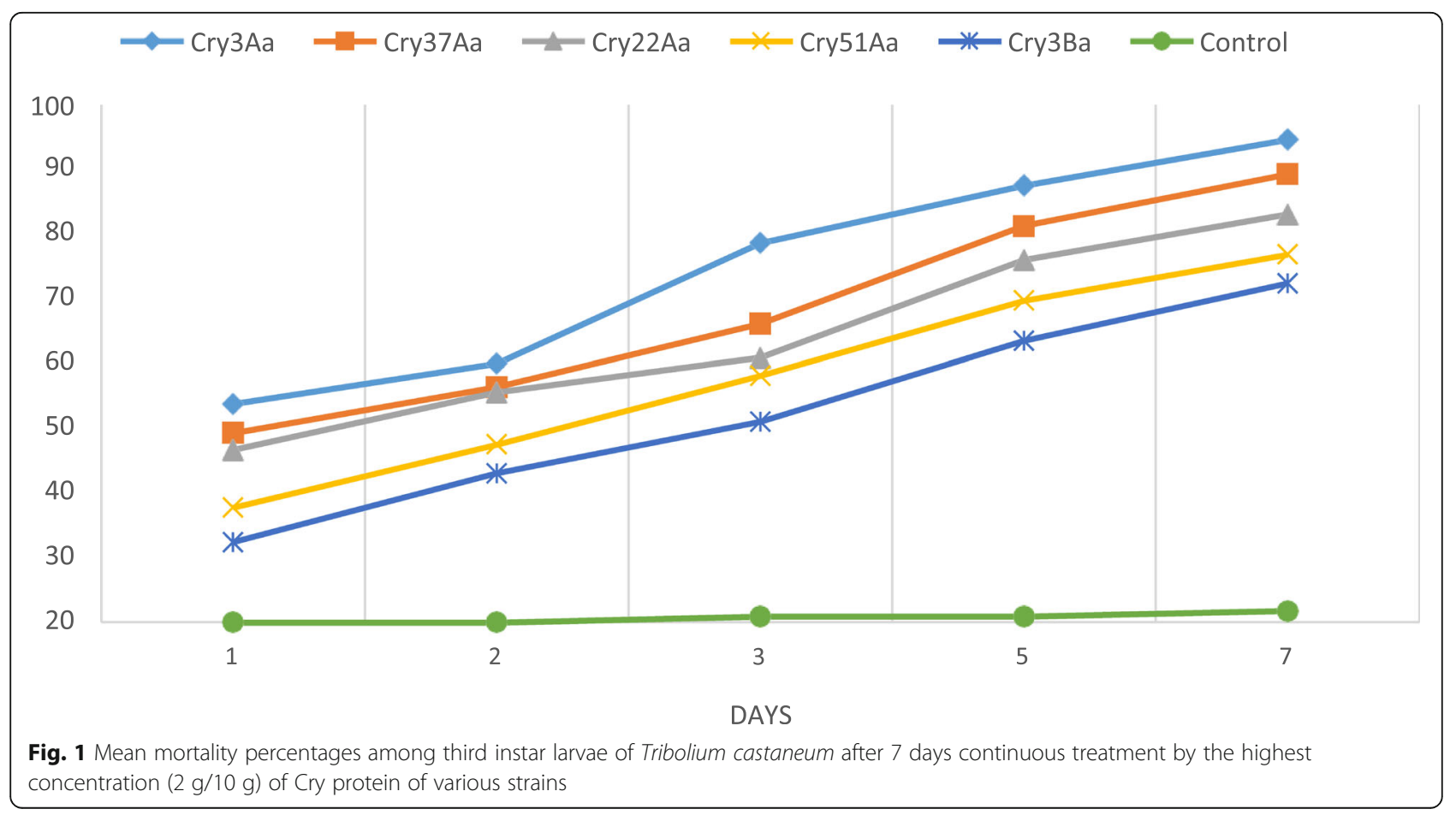


Table 4 Sublethal effects of LC30 values of five Bt strains/Cry proteins on certain biological aspects of Tribolium castaneum

\begin{tabular}{|c|c|c|c|c|c|c|}
\hline \multirow[t]{2}{*}{ Biological aspects } & \multicolumn{6}{|c|}{ Bt strains/Cry protein } \\
\hline & $\begin{array}{l}20140919 \text { KYYT015 } \\
\text { Cry3Aa }\end{array}$ & $\begin{array}{l}\text { 20150420LHMT145 } \\
\text { Cry37Aa }\end{array}$ & $\begin{array}{l}20141126 C L L T 002 \\
\text { Cry22Aa }\end{array}$ & $\begin{array}{l}\text { 20131204YWYT028 } \\
\text { Cry51Aa }\end{array}$ & $\begin{array}{l}20140728 \mathrm{LTT} 243 \\
\text { Cry3Ba }\end{array}$ & Control \\
\hline $\begin{array}{l}\text { Total eggs laid by } T \text {. castaneum } \\
\text { female during two weeks }\end{array}$ & $418.66 \pm 7.78^{F}$ & $520.16 \pm 8.97^{\mathrm{E}}$ & $581.5 \pm 8.97^{\mathrm{D}}$ & $650.16 \pm 4.07^{C}$ & $693.33 \pm 5.50^{B}$ & $846.66 \pm 7.08^{\mathrm{A}}$ \\
\hline Percent decrease in egg numbers & 50.55 & 38.56 & 31.31 & 23.20 & 18.10 & - \\
\hline $\begin{array}{l}\text { Total eggs hatching per female } \\
\text { during two weeks }\end{array}$ & $329.50 \pm 8.40^{F}$ & $426.16 \pm 5.98^{\mathrm{E}}$ & $481.16 \pm 4.44^{\mathrm{D}}$ & $555.66 \pm 4.32^{c}$ & $622.50 \pm 4.63^{B}$ & $804.16 \pm 8.10^{A}$ \\
\hline Hatchability rate of eggs & $78.70 \%$ & $81.92 \%$ & 82.74 & 85.46 & 89.78 & $94.98 \%$ \\
\hline Pre-oviposition period (day) & $6.83 \pm 0.75^{\mathrm{A}}$ & $6.12 \pm 0.75^{\mathrm{AB}}$ & $5.60 \pm 0.89 B C$ & $5.33 \pm 1.03^{\mathrm{BCD}}$ & $4.16 \pm 0.75^{C D}$ & $4.66 \pm 0.51^{C D}$ \\
\hline Incubation period of eggs (day) & $3.50 \pm 0.54^{c}$ & $4.50 \pm 0.54^{\mathrm{B}}$ & $5.16 \pm 0.98^{\mathrm{AB}}$ & $5.83 \pm 0.98^{\mathrm{A}}$ & $6.00 \pm 0.75^{\mathrm{A}}$ & $5.16 \pm 0.75^{\mathrm{AB}}$ \\
\hline Larval stage duration (day) & $21.16 \pm 1.03^{C}$ & $22.16 \pm 2.99^{B C}$ & $23.83 \pm 1.04^{\mathrm{AB}}$ & $25.50 \pm 1.04^{\mathrm{A}}$ & $25.83 \pm 1.21^{\mathrm{A}}$ & $24.66 \pm 0.81^{A}$ \\
\hline Pupal stage duration (day) & $3.83 \pm 0.75^{\mathrm{D}}$ & $4.50 \pm 0.83^{\mathrm{BCD}}$ & $5.33 \pm 1.03^{\mathrm{ABC}}$ & $5.83 \pm 0.75^{A B}$ & $6.33 \pm 0.51^{\mathrm{A}}$ & $4.83 \pm 0.75^{C}$ \\
\hline $\begin{array}{l}\text { Total development period of } \\
\text { immature stages (day) }\end{array}$ & 28.66 & 31.16 & 33.99 & 37.16 & 38.13 & 34.65 \\
\hline
\end{tabular}

Means followed by the same letter in a row are not significantly different at 0.05 level of probability

Letters above each treatment indicate significance between various Bt strains and control. Treatments with the same letter are not significantly different

revealed that treatment of $T$. castaneum adults with $\mathrm{LC}_{30}$ of 5 Cry proteins reduced significantly the number of daily deposited eggs per female throughout an observation period of 2 weeks by 50.55, 38.56, 31.31, 23.20, and $18.1 \%$ for Cry3Aa, Cry37Aa, Cry22Aa, Cry51Aa, and Cry3Ba, respectively. The pre-ovipositional period of females was prolonged by all Cry proteins, except Cry3Ba with which this period was decreased. The hatchability rates of daily laid eggs/female were significantly reduced with $5 \mathrm{Bt}$ strains/Cry protein than the control. There were remarkable differences between the treatments and the control for the total larval and the pupal durations and total developmental period of immature stages.

These results are on the same line with those obtained by Desneux et al. 2007 who stated that the $\mathrm{LC}_{30}$ was chosen for sublethal effect studies because it is the mortality threshold (30\%) recommended for the use of pesticides in integrated pest management, and therefore it is crucial in assessing possible sublethal effects on pests. These sublethal effects should be evaluated because they could have a strong impact on the population dynamics of lepidopteran pests and could contribute to its management (Pineda et al. 2009). In the present study, some of the biological parameters, such as total daily laid eggs/female for 2 weeks, hatchability rate of eggs, pre-ovipositional period, and incubation period of eggs, larval and pupal stage durations and total developmental period of immature stages of $T$. castaneum were evaluated after exposure to the active $5 \mathrm{Bt}$ strain/Cry protein. In addition, Abedi et al. 2014 studied the lethal and sublethal effects of $B t$ subsp. kurstaki on third instar larvae of Heliothis armigera under laboratory conditions. Their results showed that the application of $\mathrm{LC}_{30}$ value of $B t$ reduced the larval and pupal weights and increased larval and pupal durations. The longevity and fecundity of female adults were affected significantly by the bioinsecticides.
Female fecundity was reduced by treatments. In addition, Nouri-Ganbalani et al. 2016 studied the toxicity and biological effects of $B t$ strains on third instar larvae of Plodia interpunctella under laboratory conditions. The high mortality of larvae, growth retardation, including reduced larval and pupal weight, and prolongation of immature stages development were recorded in the treatment. Similar effects were observed in the present study. Adults of several important coleopteran pests have been reported previously to suffer reduced fecundity after exposure to pesticides (Pineda et al., 2009). In the present study also, $B t$ strains/Cry proteins caused reduced fecundity and successful pupation of T. castaneum.

\section{Total carbohydrate, lipid, and protein determinations}

The results of the total carbohydrates, lipid, and protein in 7-14-day-old larvae of $T$. castaneum after fed on a diet containing $\mathrm{LC}_{30}$ of Cry proteins for 5 days are displayed in Table 5 and showed a statistically significant reduction in energy reserves in comparison to control larvae. Exposure to the $\mathrm{LC}_{30}$ of Cry3Aa resulted in greater magnitude in the reduction $72.5,77$, and $37.3 \%$ in protein, glycogen, and lipid content, respectively, in comparison to untreated (control) larvae. While exposure to $\mathrm{LC}_{30}$ of Cry37Aa resulted in reductions in protein (53.6), glycogen $(71.30 \%)$, and lipid (27.21\%) content, in comparison to control larvae.

The mean total carbohydrate, lipid, and protein contents in all treatments were significantly reduced than control. The decrease in protein content was observed in the larvae fed on treated wheat barn than the control larvae. Reduction in protein content is a common phenomenon in insects after treatment with toxic compounds (Nathan et al. 2008). The present results are supported by several reports where the toxicity of $B t$ strains caused a reduced protein content of insects (Abedi et al. 2014). Lipids are an important source of 
Table 5 Energy reserves of treated third instar larvae of Tribolium castaneum at LC30 of Bt strains/Cry protein after 5 days of continuous exposure to the insecticide

\begin{tabular}{|c|c|c|c|c|c|c|}
\hline \multirow{2}{*}{$\begin{array}{l}\text { BT strains/Cry } \\
\text { protein }\end{array}$} & \multicolumn{2}{|l|}{ Total proteins } & \multicolumn{2}{|c|}{ Total carbohydrates } & \multicolumn{2}{|l|}{ Total lipids } \\
\hline & $\begin{array}{l}\text { Activity } \\
\text { (mean } \pm \text { S.E.) }\end{array}$ & $\begin{array}{l}\text { Percent of } \\
\text { decrease (\%) }\end{array}$ & $\begin{array}{l}\text { Activity } \\
\text { (mean } \pm \text { S.E.) }\end{array}$ & $\begin{array}{l}\text { Percent of } \\
\text { decrease (\%) }\end{array}$ & $\begin{array}{l}\text { Activity } \\
\text { (mean } \pm \text { S.E.) }\end{array}$ & $\begin{array}{l}\text { Percent of } \\
\text { decrease (\%) }\end{array}$ \\
\hline Control & $27.38 \pm 3.38^{\mathrm{A}}$ & - & $53.53 \pm 2.59^{A}$ & - & $1.58 \pm 0.35^{\mathrm{A}}$ & $\overline{-}$ \\
\hline $\begin{array}{l}\text { 20140919KYYT015 } \\
\text { Cry3Аа }\end{array}$ & $7.53 \pm 2.07^{\mathrm{D}}$ & -72.49 & $12.35 \pm 1.90^{\mathrm{D}}$ & -76.92 & $0.99 \pm 0.12^{B C}$ & -37.34 \\
\hline $\begin{array}{l}\text { 20150420LHMT145 } \\
\text { Cry37Aa }\end{array}$ & $12.68 \pm 2.47^{C}$ & -53.68 & $15.36 \pm 2.99^{\mathrm{D}}$ & -71.30 & $1.15 \pm 0.16^{\mathrm{B}}$ & -27.21 \\
\hline $\begin{array}{l}\text { 20141126CLLT002 } \\
\text { Cry22Aa }\end{array}$ & $14.28 \pm 1.84^{c}$ & -47.84 & $28.23 \pm 3.06^{C}$ & -47.26 & $0.80 \pm 0.06^{C}$ & -49.36 \\
\hline $\begin{array}{l}\text { 20131204YWYT028 } \\
\text { Cry51Aa }\end{array}$ & $16.68 \pm 1.49 B^{C}$ & -39.07 & $17.20 \pm 2.02^{\mathrm{D}}$ & -67.86 & $0.07 \pm 0.02^{\mathrm{D}}$ & -95.56 \\
\hline $\begin{array}{l}20140728 \mathrm{LTT} 243 \\
\text { Cry3Ba }\end{array}$ & $20.22 \pm 2.05^{B}$ & -26.15 & $34.21 \pm 2.94^{\mathrm{B}}$ & -36.09 & $0.17 \pm 0.02^{\mathrm{D}}$ & -89.24 \\
\hline
\end{tabular}

Letters indicate significance between strains. Means in columns with the same letter are not significantly differ

energy and are reserved in fat bodies. The reserve of lipids during the feeding period increased but was reduced in the non-feeding stage, and their amount can vary with growth stage and feeding condition (Nouri-Ganbalani et al. 2016).

\section{Digestive enzyme activity in midgut from $T$. castaneum after Cry protein treatments}

The midgut of third instar T. castaneum larvae after 5 days of continuous feeding on Cry proteins showed, statistically, significant reductions in $\alpha$-amylase and general protease activities than the midguts from control larvae (Fig. 2). Specifically, the midguts from larvae that fed on a diet containing an $\mathrm{LC}_{30}$ concentration of Cry3Aa showed only 52 and $68 \%$ of the a-amylase and general protease activities, respectively, found in midguts of the control larvae. Similarly, midguts from larvae that fed on a diet containing the $\mathrm{LC}_{30}$ of Cry37Aa showed only 42 and $56 \%$ of the a-amylase and general protease

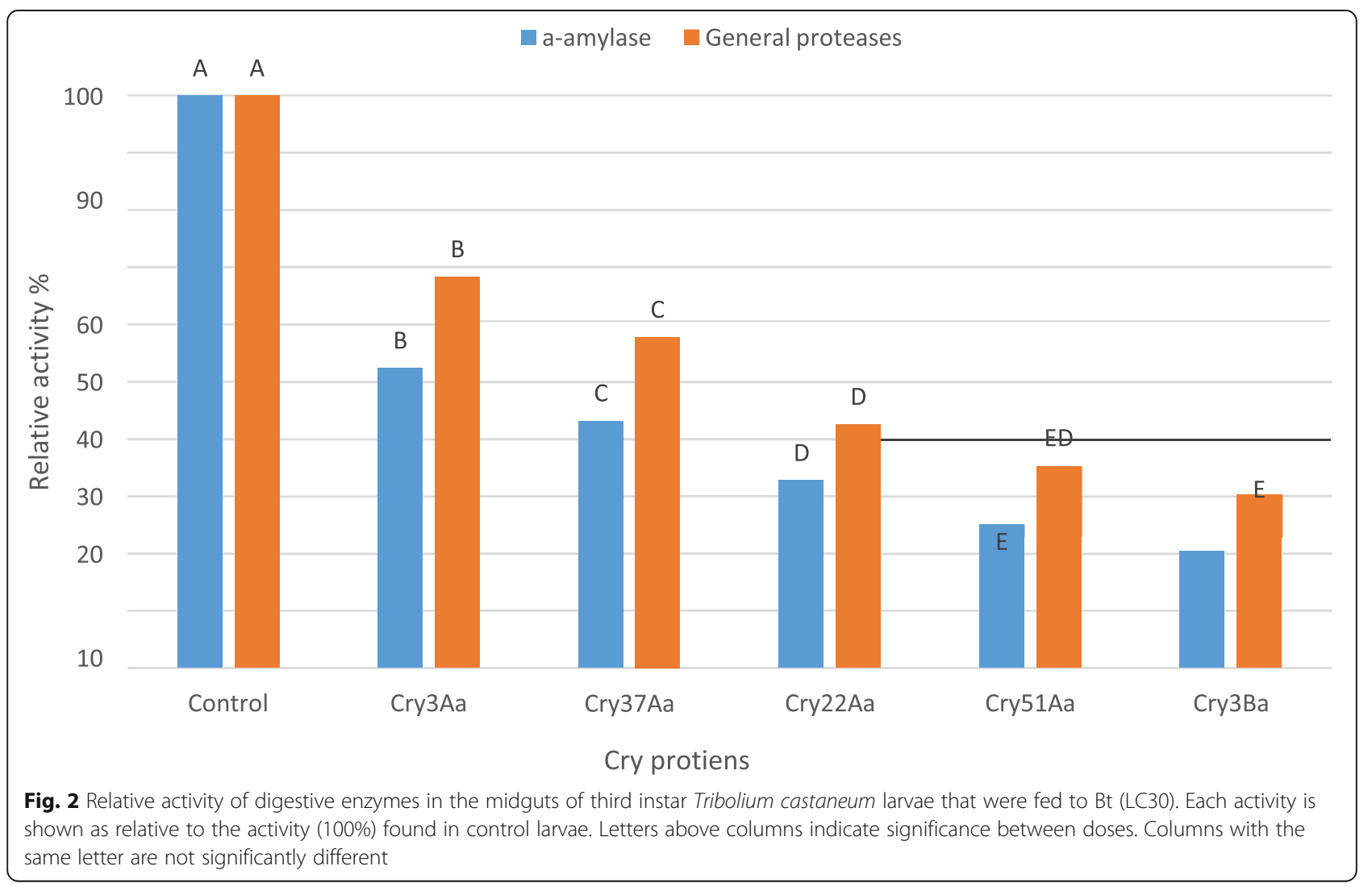


activities, respectively, found in control midguts. Midguts from larvae that fed on a diet containing $\mathrm{LC}_{30}$ of Cry3Ba showed lower a-amylase and general protease activities (20 and 30\%, respectively) in comparison to midguts from control larvae, and in comparison to midguts from larvae that fed on a diet containing only one of the insecticides (Fig. 2).

\section{Conclusion}

The results of the present study showed that $T$. castaneum was susceptible to Cry3Aa, Cry37Aa, Cry22Aa, Cry51Aa, and Cry3Ba. The results indicated that $B t$ strains/Cry proteins, negatively, affected the total daily laid eggs per female for 2 weeks, the hatchability rate of eggs and the larval and pupal durations, while, those increased the preovipositional period of T. castaneum. Obtained data revealed that $B t$ strains/Cry proteins had a high potential for controlling T. castaneum. After laboratory studies, more attention should be devoted to stored grain evaluations to obtain more applicable results.

\section{Abbreviations}

ANOVA: Analysis of variance; Bt: Bacillus thuringiensis; $\mathrm{CaCO}_{3}$ : Calcium carbonate; Cry: Crystalline; $\mathrm{K}_{2} \mathrm{HPO}_{4}$ : Dipotassium phosphate; $\mathrm{LC}_{50}$ : The median lethal concentration; $\mathrm{LT}_{50}$ : The median lethal time;

$\mathrm{MgSO}_{4}$ : Magnesium sulfate; $\mathrm{NaCl}$ : Sodium chloride

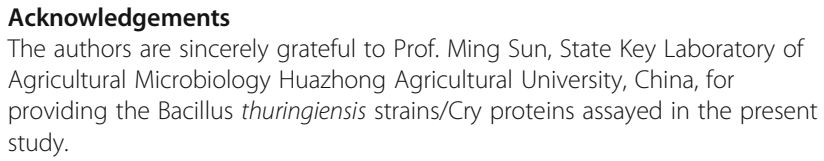

Acknowledgements

The authors are sincerely grateful to Prof. Ming Sun, State Key Laboratory of Agricultural Microbiology Huazhong Agricultural University, China, for providing the Bacillus thuringiensis strains/Cry proteins assayed in the present study.

\section{Authors' contributions}

The authors have equal contributions to this work. KE and NA released the research idea, design the research experiments, the main conceptual ideas, and proof outline, and performed the research experiments. KE screened the toxicity bioassay experiment and digestive enzyme activity assays. NA performed the microbiology and biochemical analysis experiments. EK and NA analyzed the data and wrote the manuscript. All authors read and approved the final manuscript.

\section{Funding}

There are no funding sources for this manuscript.

\section{Availability of data and materials}

The data and material of this manuscript are available upon reasonable request.

\section{Ethics approval and consent to participate}

This article does not contain any studies with human participants or animals.

\section{Consent for publication}

Neither the manuscript nor any part inside has been published elsewhere.

\section{Competing interests}

The authors declare that they have no competing interests.

\section{Author details}

${ }^{1}$ College of Life Science and Technology, Huazhong Agricultural University, Wuhan 430070, China. ${ }^{2}$ Plant Protection Department, Faculty of Agriculture, Benha University, Toukh 13736, Egypt. ${ }^{3}$ Agriculture Microbiology Department, Faculty of Agriculture, Benha University, Toukh 13736, Egypt.
Received: 20 October 2019 Accepted: 10 December 2019

Published online: 30 December 2019

\section{References}

Abbott WS (1925) A method of computing the effectiveness of an insecticide. J Econ Entomol 18:265-267

Abedi Z, Saber M, Vojoudi S, Mahdavi V, Parsaeyan E (2014) Acute, sublethal, and combination effects of azadirachtin and Bacillus thuringiensis on the cotton bollworm, Helicoverpa armigera. J Insect Sci 14:817-821

Bernfeld P (1955) Amylases, a and b. Methods Enzymol 1:149-158

Borzoui E, Bandani AR (2013) Wheat and triticale proteinaceous seed extracts inhibit gut a-amylase and protease of the carob moth, Ectomyelois ceratoniae. Mol Entomol. 4:13-21

Bravo A, Gill SS, Soberón M (2007) Mode of action of Bacillus thuringiensis Cry and Cyt toxins and their potential for insect control. Toxicon 49:423-435

Cannon RJ (1993) Prospects and progress for Bacillus thuringiensis-based pesticides. Pesticide Sci 37:331-335

Crickmore N, Baum J, Bravo A, Lereclus D, Narva K, Sampson K, Schnepf E, Sun M, Zeigler DR (2014) Bacillus thuringiensis toxin nomenclature. http://www. btnomenclature.info/

Crickmore N, Zeigler DR, Feitelson J, Schnepf E, Van Rie J, Lereclus D, Baum J, Dean DH (1998) Revision of the nomenclature for the Bacillus thuringiensis pesticidal crystal proteins. Microbiol Mol Biol 62:807-813

Desneux N, Decourtye A, Elpuech JM (2007) The sublethal effects of pesticides on beneficial arthropods. Ann Rev Entomol 52:81-106

Elpidina EN, Vinokurov KS, Gromenko VA, Rudenskaya YA, Dunaevsky YE, Zhuzhikov DP (2001) Compartmentalization of proteinases and amylases in Nauphoeta cinerea midgut. Arch Insect Biochem Physiol 48:206-216

Ferre J, Van Rie J (2002) Biochemistry and genetics of insect resistance to Bacillus thuringiensis. Annu Rev Entomol 47:501-533

Finney DJ (1971) "Probit Analysis". Cambridge University Press, Cambridge, London, 333pp.

Gilliland A, Chambers CE, Bone EJ, Ellar DJ (2002) Role of Bacillus thuringiensis Cryld endotoxin binding in determining potency during lepidopteran larval development. Appl Environ Microbiol 68:1509-1515

Gould F (1998) Sustainability of transgenic insecticidal cultivars: integrating pest genetics and ecology. Annu Rev Entomol 43:7017-7026

Hernandez CS, Rodrigo A, Ferré J (2004) Lyophilization of lepidopteran midgets: a preserving method for Bacillus thuringiensis toxin binding studies. J Invertebr Pathol 85:182-187

Jembere B, Obeng-Ofori D, Hassanli L, Nyamasyo GN (1995) Products derived from the leaves of Ocimum kilimannd scharium (Labiatae) as post-harvest grain protectants against the infestation of three major stored product insect pests. Bull Entomol Res 85:361-367

Lemaux PG (2008) Genetically engineered plants and foods: a scientist's analysis of the issues (part I). Annu Rev Plant Biol 59:771-812

López-Pazos SA, Cortázar-Gómez JE, Cerón-Salamanca JA (2009) Cry1B and Cry3A are active against Hypothenemus hampei Ferrari (Coleoptera: Scolytidae). J Invertebr Pathol 101:242-245

Lowry OH, Rosebrough NJ, Farr AL, Randall RJ (1951) Protein measurement with the Folin phenol reagent. J Biol Chem 193:265-275

Maclntosh SC, Stone TB, Sims SR, Hunst PL, Greenplate JT, Marrone PG, Perlak FJ, Fischhoff DA, Fuchs RL (1990) Specificity and efficacy of purified Bacillus thuringiensis proteins against agronomically important insects. J Invertebr Pathol 56:258-266

Magda AE (2006) Bacillus thuringiensis and Bacillus sphaericus biopesticides production. J Basic Microbiol 46(2):158-170

Marrone PG, and Macintosh SC (1993) Resistance to Bacillus thuringiensis and resistance management. In: P.F. Entwistle JS, Cory MJ, Higgs S (eds.) Bacillus thuringiensis an environmental biopesticide: theory and practice. Hon Wiley, Chichester, England. 221-235.

Nathan S, Choi MY, Seo HY, Paik CH, Kalaivani K, Kim JD (2008) Effect of azadirachtin on acetylcholineesterase activity and histology of brown plant hopper Nilaparvata lugens (Stal.) Ecotox. Environ Safety 70:244-250

Nouri-Ganbalani G, Borzoui E, Abdolmaleki A, Abedi Z, Kamita SG (2016) Individual and Combined Effects of Bacillus thuringiensis and Azadirachtin on Plodia Interpunctella (Hübner) (Lepidoptera: Pyralidae). J Insect Sci 16(1):1-8

Pineda S, Martinez AM, Figueroa JI, Schneider MI, Estal DP, Estal VE, Gomez B, Smagghe G, Budia F (2009) Influence of Azadirachtin and Methoxyfenozide on Life parameters of Spodoptera littoralis (Lepidoptera: Noctuidae). J Econ Entomol 102(4):1490-1496 
Poutanen K (2012) Past and future of cereal grains as food for health. Trends Food Sci Technol 25:58-62

Steel RG, Torrie JH, Dickey D (1997) Principles and Procedure of Statistics. A Biometrical Approach $3^{\text {rd }}$ Ed. McGraw Hill BookCo. Inc., New York, pp 352-358

Tabashnik BE, Carriere Y, Dennehy TJ, Morin S, Sisterson M, Roush RT, Shelton AM, Zhao JZ (2003) Insect resistance to transgenic Bt crops: lessons from the laboratory and field. J Econ Entomol 96:1031-1038

Tamez-Guerra P, Iracheta MM, Pereyra-Alferez B, Galan-Wong LJ, Gomez-Flores R, Tamez-Guerra RS, Rodriguez-Padilla C (2004) Characterization of Mexican Bacillus thuringiensis strains toxic for lepidopteran and coleopteran larvae. J Invertebr Pathol 86(1):7-18

Toews MD, Arthur FH, Campbell JF (2005) Role of food and structural complexity on capture of Tribolium castaneum (Herbst) (Coleoptera: Tenebrionidae) in simulated warehouses. Environ Entomol 34(1):164-169

Van Frankenhuyzen K (2009) Insecticidal activity of Bacillus thuringiensis crystal proteins. J Invert Pathol 101:1-16

Van Handel E (1985) Rapid determination of total lipids in mosquitoes. J Am Mosq Control Assoc 1:302-304

Weston PA, Rattlingourd PL (2000) Progeny production by Tribolium castaneum (Coleoptera: Tenebrionidae) and Oryzaephilus surinamensis (Coleoptera: Silvanidae) on maize previously infested by Sitotroga cerealla (Lepidoptera: Gelechiidae). J Econ Entomol 93:533-536

Yu HL, Li YH, Wu KM (2011) Risk assessment and ecological effects of transgenic Bacillus thuringiensis crops on non-target organisms. J Integr Plant Biol 53: 520-538

Yuval B, Kaspi R, Shloush S, Warburg MS (1998) Nutritional reserves regulate male participation in Mediterranean fruit fly leks. J Ecol. Entomol. 23:211-216

\section{Publisher's Note}

Springer Nature remains neutral with regard to jurisdictional claims in published maps and institutional affiliations.

\section{Submit your manuscript to a SpringerOpen ${ }^{\circ}$ journal and benefit from:}

- Convenient online submission

- Rigorous peer review

- Open access: articles freely available online

High visibility within the field

- Retaining the copyright to your article

Submit your next manuscript at $\boldsymbol{\nabla}$ springeropen.com 